\title{
Store Image as a Mediator of Consumer Purchase Intention in Kenyan Supermarkets
}

\author{
Grace Wambui Kiboro $^{1 *} \quad$ Mike Iravo $^{2} \quad$ Doris Mbugua $^{3} \quad$ Edward Owino $^{4}$ \\ 1.PhD. Candidate, School of Business, Jomo Kenyatta University of Agriculture and Technology \\ 2.Professor, School of Business, Jomo Kenyatta University of Agriculture and Technology \\ 3.Lecturer, School of Business, Jomo Kenyatta University of Agriculture and Technology \\ 4.Senior Lecturer, School of Business, KCA University \\ P.O. Box 62000 - 00200 Nairobi, Kenya
}

\begin{abstract}
The intensity of competition in the retail sector in Kenya is driving supermarket managers to position store image as a tool of competitive advantage. This study examined the mediating effect of store image on the relationship between psychographic and psychological factors and consumer purchase intention in anchor supermarkets in Kenya. Descriptive cross sectional survey was applied on a sample of 384 consumers. The composite construct of psychographic and psychological factors was regressed on consumer purchase intention, resulting in a positive significant effect. It was established that store image partly mediates the relationship between psychographic plus psychological factors and consumer purchase intention. The study recommends building of positive reputation of the supermarket to attract and enhance the consumer's intention to purchase.
\end{abstract}

Keywords: Store image, purchase intention, anchor supermarkets

DOI: $10.7176 / \mathrm{JMCR} / 66-06$

Publication date:March $31^{\text {st }} 2020$

\section{Introduction}

The idea of a supermarket was advanced by Clarence Saunders, an entrepreneur in 1916 when he opened his Piggly Wiggly stores. According to Lawrence and Dixon (2015), increased global liberalization has opened enormous opportunities for the expansion of the supermarket business. Borrowing from Berdegue and Reardon (2016), consumer purchasing trends have changed such that more consumers have moved away from buying from small grocery stores to purchasing in supermarkets. Retailers, including anchor tenants, operating supermarkets in shopping malls in developed countries have been struggling to attract consumers to shop from their stores. However, in Africa, shopping malls are generally transforming local economies by riding on strong anchors retailers (Birkner, 2015). For instance, Carrefour, a leading retailer from France opened supermarkets in Egypt and Kenya where they anticipated fast growth since the retail industry was not fully developed (das Nair, 2018). Competitiveness amongst retailers has been on the rise and this challenge requires managers to outwit their rivals in attracting consumers to their supermarkets. In the face of competition, Mbugua (2015) suggest that it is necessary for supermarkets to adopt strategies that put customers at the centre of their marketing activities to successfully sway consumers to shop from their stores as opposed to those of their competitors. Ray et al. (2015) in their research focused on the influence of lifestyle and personality of consumers purchase intention in Kolkata, India. Naeini, Azali, and Tamaddoni (2015) in Iran focused on the effect of perception on consumer purchase intention leaving out motivation, lifestyle and personality factors which are pertinent to consumer decision making. Empirical evidence shows the existence of significant relationship between psychographic and psychological factors and consumer purchase intention. The role of store image in this association remains ambivalent. This study sought to determine the mediating effect of store image on the relationship between psychographic and psychological factors and consumer purchase intention in supermarkets in Nairobi, Kenya.

\section{Literature Review}

Store Image represents the mental view shoppers have regarding a retailer in terms of customer service, type of products available, look and feel of the outlet as well as the experience consumers expect in the course of their shopping (Hussain \& Ali, 2015). The consumers' positive opinions about the reputation of the supermarket make them want to purchase from that store which calls for retailers to make sure their store is viewed positively (Cho \& Fiore, 2015). The store atmosphere and in particular cleanliness, lighting, scent, displays and layout had a significant and positive effect on consumers wanting to buy from a retailer (Hussain \& Ali, 2015). Also, pleasant music in the shopping atmosphere makes consumers comfortable and so they stay longer browsing and buying from the store (Vaccaro, Yucetepe, Cohn, \& Dunne, 2017). Retailers ought to create a pleasant store ambience to attract consumers to buy from their stores. According to Sehgal and Khanna (2017) the assistance consumers receive during shopping greatly influence their perception of the store image.

Shoppers' store image perception arises from a number of attributes including price charged for products, 
brand portfolios and perceived risk associated with the purchase. Affordable pricing, wide product range and a goods return policy create a favourable reputation of the retailer (Erdil, 2015). Supermarkets should convince consumers about value for money pricing in order to encourage them to purchase from their stores. Further, store image mediates the relationship between consumer perceptions of a supermarket based on the quality of products sold. Supermarkets must stock quality portfolio to make sure it portrays them positively because when consumers perceive risk associated with products provided by the supermarket, they develop a negative store image and are not willing to purchase from it. It is necessary for the supermarket to project a strong image through professional service and the brands offered to draw consumers to buy from them (Alamsyah \& Hariyanto, 2017).

Conversely, consumers can develop negative opinions towards a supermarket that creates a bad attitude towards it which makes them buy from their rivals (Chong, Li, Ngai, Ch'ng, \& Lee, 2016). This often arises when consumers are unhappy with issues like long check-out lines, congested/dark/unlabelled aisles; limited range of products, unfriendly/unsupportive staff and poor hygiene of products/store. In such a case, retailers need to speedily correct such issues causing negative sentiments towards their outlet to avoid loss of business. Through effective communication on the store characteristics, customer service and products features, the supermarkets can create a positive store image. This would encourage shoppers to patronize their stores often (Alamsyah, Suhartini, Rahayu, Setyawati, \& Hariyanto, 2018). Supermarkets need to leverage on the aspects that improve store image through quality service by employing professional and helpful staff to influence consumers to visit their stores (Kaborio, Kamau, \& Mbithi, 2017). Supermarkets cannot ignore the part played by store image in this competitive business and should take advantage of every opportunity to boost customer service. Consumers care about the image of the supermarkets they buy from and when they are happy with the retailers' image, they buy from that store often (Muturi, Omwenga, \& Owino, 2018). A positive store image offers a competitive edge for a supermarket by providing a unique position relative to competitors.

In Kenya, the Nakumatt chain of supermarkets' reputation of empty shelves caused a serious decline in the number of shoppers visiting the stores; so that even the few products available had no buyers. In spite of the retailer's loyalty program, most consumers had no reason to visit the stores (Chanya, 2017). Although Nakumatt tried a comeback, their reputation had sunk too low for enough consumers to patronize their stores to keep their business afloat. A worrying trend is seen among retailers, especially those located in shopping malls in developed nations, who are faced with an uphill task of attracting consumers to buy from them. Conversely, in Africa, shopping malls are growing retail businesses driven by robust anchors retailers (Birkner, 2015). Carrefour, a principal retailer from France has established supermarkets in Africa (Egypt and Kenya) where supermarket business has not yet fully developed in anticipation of fast growth (das Nair, 2018). This retailer has embarked on building a positive corporate reputation through competitive pricing, variety of products and customer service to out-wit competitors to draw more shoppers traffic to their stores (Wang, 2019).

Several earlier studies have revealed that store image influences purchase intention of consumers (Kaihatu \& Spence, 2016; Makanyeza \& Chikazhe, 2017; Ofori, Boakye, \& Narteh, 2018). Nevertheless, the extent to which store image influences store patronage is unclear. Besides, the results from related research disclose an inconsistent association between store image and customer loyalty which influences supermarkets the shoppers buy from (Mohd Suki, 2017). Nonetheless, other studies established that corporate reputation influences consumers to buy from a supermarket frequently (Makanyeza \& Chikazhe, 2017). From the foregoing discussion, it is possible that situations exist when consumers are likely to use store image to assess a supermarket's appropriateness for their patronage. However, retailers do not have clear guidelines on relevant store image drivers to leverage on. This study sought to shed more light on the mediating role of store image in relation to purchase intention of consumers from supermarkets.

The supermarket business flourishes on high consumer traffic that patronizes their stores while as a declining number shoppers spells doom for the stores. Retailers use loyalty programs to draw more customers from competitors to patronize their stores repeatedly to bring more business (Muturi et al., 2018). In Malaysia, price perception was examined as a mediating variable but store image was omitted (Lam, 2016). Store image has been examined as a moderating variable in stand-alone supermarkets but its mediating influence on purchase intention, and moreover in anchor supermarkets, was left out (Erdil, 2015; Gichunge, Ernest, \& Bonuke, 2017; Kiriri, 2019). Besides, in Africa including Kenya, shopping malls are growing local retail businesses driven by robust anchors retailers (Birkner, 2015). High end anchor stores like Carrefour and Shoprite are increasing attracting shoppers to their stores though it is not clear why this trend is being observed (Harris, Roby, \& Dibb, 2016). In view of the knowledge gaps in the foregoing discussion, this research seeks to determine the influence of store image on consumers in anchor supermarkets in Nairobi, Kenya.

While store image is pertinent to purchase intention, most studies on store image have been conducted outside Africa in developing counties like America or Europe (Diallo \& Cliquet, 2016; Wang, 2019). Moreover, it is important to provide a relevant tool that shows how anchor supermarket managers can effectively apply store image to influence customers to purchase in their stores based on scientific triangulation research findings. 


\section{Methodology}

Guided by a positivist research philosophy a descriptive cross sectional survey was employed akin to previous scholars (Erdil, 2015; Gichunge et al., 2017; Muturi et al., 2018). Using cluster sampling, the population was divided into quotas and a sample of 384 respondent drawn. The quotas of interest were the twelve groups of anchor supermarkets. Convenience sampling was applied in selecting consumers who were 18 years and above and mall intercept technique applied in the final process of selecting the 10th customer entering the supermarket (Malhotra, 2018). The questionnaires were structured for convenience of response and a five point Likert scale applied in conformance to Owino et al. (2014). The questionnaire was pilot tested for validity and reliability using the Mugenda and Mugenda (2013) criteria, with no violation noted. Descriptive statistical test and inferential statistical test were applied (Holcomb, 2016; Saunders, Lewis, \& Thornhill, 2016). Diagnostic test of the data was performed using; Shapiro-Wilk test for normality of the distribution (Razali \& Wah, 2011), Variance Inflation Factor (VIF) and Tolerance measure were applied in testing for presence of multicollinearity and the BreuschPagan Test applied testing for homoscedasticity of the data. No violation of the assumptions of regression was noted.

\section{Analysis}

Using mean score analysis, it was established that store image was a multifaceted construct, comprised of several items. Using a 5 point Likert scale, the items with the highest mean score were; ability of Supermarket to offer a wide range of products to select from (mean score $=4.42$ ), affordability of products (mean score $=4.19$ ), willingness of supermarket staff to guide customers (mean=4.17), reputation of the supermarket (mean=3.99), the background music of the store makes me feel peaceful (mean=3.97), the scent/fragrance/ aroma enhances consumer mood $(m e a n=3.88)$ and the air conditioning makes me feel comfortable (mean=3.87). The average mean score of the store image construct was 3.95 , which meant that most of the participants agreed that store image influenced their purchase intentions.

The study tested for mediation using multiple regression analysis, where the principal notion regarding a mediating variable was that it in some way intervenes in the process of transformation between stimuli and response (Baron \& Kenny, 1986). In assessment of the mediating effect, the estimation by Ordinary Least Squares (OLS) method was applied and a three step procedure by Baron and Kenny (1986) applied. In the first step, the psychographic and psychological factors were regressed against consumer purchase intention and resulting in a statistically significant model ( $\mathrm{p}$-value $=0.000, \beta=1.080$ ). In the second step, psychographic and psychological were regressed against store image and the resulting coefficients were statistically significant ( $p$-value $=0.000$, $\beta=0.948$ ). This meant that the model predicted by psychographic and psychological factors significantly explained the linear link between the psychographic plus psychological factors and store image. In the third step, the mediating effect of the image of the store on the relationship amongst psychographic, psychological and consumer purchase intention was tested under the following hypothesis;

$\mathrm{H}_{0}$ : $\quad$ Store image has no significant mediating effect on the relationship between

psychographic and psychological factors and consumer purchase intention in supermarkets in Kenya.

From the model summary of the mediated relationship, the coefficient of determination $\left(\mathrm{R}^{2}\right)=0.666$ which meant that model explained $66.6 \%$ of the variations in purchase intention, implying the model generated a moderately good fit. From Table 1, the coefficient of psychographic and psychological factors was significant (pvalue $=0.000, \beta=0.726)$. Store image had a significant coefficient $(p$-value $=0.000, \beta=0.373)$. This meant that because the beta coefficient of store image is statistically significant, then since beta coefficient was statistical significance in the second step, the elucidation is that store image mediates the connection amongst psychographic plus psychological factors and consumer purchase intention.

Table 1: Coefficients of Store Image, Psychographic and Psychological Factors

\begin{tabular}{|c|c|c|c|c|c|c|c|}
\hline \multirow{2}{*}{ Model } & & \multicolumn{2}{|c|}{$\begin{array}{c}\text { Unstandardized } \\
\text { Coefficients }\end{array}$} & \multirow{2}{*}{$t$} & \multirow{2}{*}{ Sig. } & \multicolumn{2}{|c|}{$\begin{array}{l}95.0 \% \text { Confidence } \\
\text { Interval for B }\end{array}$} \\
\hline & & $\beta$ & Std. Error & & & $\begin{array}{l}\text { Lower } \\
\text { Bound }\end{array}$ & $\begin{array}{l}\text { Upper } \\
\text { Bound }\end{array}$ \\
\hline \multirow{3}{*}{1} & (Constant) & -.234 & .160 & -1.457 & .146 & -.549 & .082 \\
\hline & $\begin{array}{l}\text { Psychographic and } \\
\text { Psychological factors }\end{array}$ & .726 & .077 & 9.449 & .000 & .575 & .877 \\
\hline & Store Image & .373 & .068 & 5.511 & .000 & .240 & .506 \\
\hline
\end{tabular}

a. Dependent Variable: Purchase Intention

The combined coefficient of psychographic and psychological factors under mediated model was evaluated. If the beta coefficient in step two was not significant, then it implied that store image completely mediated the association between psychographic plus psychological factors and consumer purchase intention. But the beta coefficient in step two was statistically significant, the study therefore rejected the null hypothesis $\left(\mathrm{H}_{0}\right)$ at $95 \%$ confidence level and interpreted the outcome to mean that store image partly mediates the relationship between psychographic plus 
psychological factors and consumer purchase intention in supermarkets in Nairobi, Kenya.

\section{Results and Recommendation}

The research established store image partly mediates the association between psychographic plus psychological factors and consumer purchase intention. In reference to the mean score analysis, the elements to pay attention to when creating a store imagery are; ability of supermarket to offer a wide range of products, affordability of products, willingness of supermarket staff to guide customers and reputation of the supermarket. Also, supermarket managers ought to consider background music in the store that makes consumer feel peaceful, the scent/fragrance/aroma that enhances consumer mood and having air conditioning that makes consumers feel comfortable. This outcome corroborate the observation made by Hussain and Ali (2015) that store ambience in terms of; scent, fragrance and aroma enhance consumers' mood which significantly influenced their desire to purchase. Kesari and Atulkar (2016) similarly note that a wide range of products and air conditioning attracted consumers to supermarkets. In addition, the findings are in line with (Kaborio et al., 2017) who established that the guidance accorded customers by supermarket staff makes customers want to come back for hassle-free shopping. Consistent with the study outcome is the position taken by Vaccaro et al. (2017) that pleasant music in the shopping atmosphere made consumers comfortable making them stay longer browsing and buying from the store. Moreover, it was observed that a positive reputation and favourable ambience encouraged consumers to repeatedly patronize the store. In addition, availability of a wide range of products was noted to be the most significant in painting a strong store image in the mind of the consumer (Gichunge et al., 2017).

The study recommends that supermarket management must endeavour to build a strong store image for competitive advantage. To achieve this, the management of supermarket stores have to formulate novel strategies that address the following; create a positive reputation of the supermarket, play background music in the store that makes consumer feel peaceful, the scent/fragrance/aroma that enhances consumer mood and having air conditioning that makes consumers feel comfortable. This physical environment is likely to not only attract more shoppers but also enhance the consumer's intention to purchase. It is recommended that supermarkets must create and aggressively communicate a competitive value preposition. Since most shoppers in the study were price sensitive, a value preposition that communicates affordability of products is more likely to trigger intention to purchase. Last, while this study examined store image as a mediating variable, future studies can examine its direct effect on consumer purchase intention when applied as a predictor variable.

\section{References}

Alamsyah, D., Suhartini, T., Rahayu, Y., Setyawati, I., \& Hariyanto, O. (2018). Green advertising, green brand image and green awareness for environmental products. Paper presented at the IOP Conference Series: Materials Science and Engineering.

Birkner, C. (2015). Music: The unsung hero of advertising. Paper presented at the American Marketing Association.

Chanya, P. M. (2017). Effect of customer loyalty programs on performance of Nakumatt supermarket in Western region in Kenya. Maseno University.

Cho, E., \& Fiore, A. M. (2015). Conceptualization of a holistic brand image measure for fashion-related brands. Journal of Consumer Marketing, 32(4), 255-265.

Chong, A. Y. L., Li, B., Ngai, E. W., Ch'ng, E., \& Lee, F. (2016). Predicting online product sales via online reviews, sentiments, and promotion strategies: A big data architecture and neural network approach. International Journal of Operations \& Production Management, 36(4), 358-383.

das Nair, R. (2018). The internationalisation of supermarkets and the nature of competitive rivalry in retailing in southern Africa. Development Southern Africa, 35(3), 315-333.

Diallo, M. F., \& Cliquet, G. (2016). Store image perceptions and customer knowledge cues in emerging markets. International Journal of Retail \& Distribution Management.

Erdil, T. S. (2015). Effects of customer brand perceptions on store image and purchase intention: An application in apparel clothing. Procedia-Social and Behavioral Sciences, 207, 196-205.

Field, A. (2013). Discovering statistics using IBM SPSS statistics: sage.

Gichunge, N. C., Ernest, S., \& Bonuke, R. (2017). The moderating effect of store image on the indirect relationship between socio-sensory experience and the purchase intention via social value.

Harris, F., Roby, H., \& Dibb, S. (2016). Sustainable clothing: challenges, barriers and interventions for encouraging more sustainable consumer behaviour. International Journal of Consumer Studies, 40(3), 309-318.

Holcomb, Z. C. (2016). Fundamentals of descriptive statistics: Routledge.

Hussain, R., \& Ali, M. (2015). Effect of store atmosphere on consumer purchase intention. International Journal of Marketing Studies, 7(2).

Kaborio, C. N., Kamau, S., \& Mbithi, M. (2017). Effect of Consumer Factors on Store Brand Choice in the Retail Industry in Kenya: A Survey of Selected Supermarkets in Nairobi County. International Journal of Business Management \& Finance, 1(20), 332-346. 
Kaihatu, T. S., \& Spence, M. T. (2016). The relationship between shopping mall image and congruity on customer behaviour: Evidence from Indonesia. Australasian Marketing Journal (AMJ), 24(2), 141-145.

Kesari, B., \& Atulkar, S. (2016). Satisfaction of mall shoppers: A study on perceived utilitarian and hedonic shopping values. Journal of Retailing and Consumer Services, 31, 22-31.

Kiriri, P. (2019). Determinants of Shopping Mall Attractiveness: the Case of Shopping Malls in Nairobi, Kenya.

Lam, J. C. (2016). The Impact of Value Perceptions on Purchasing of Luxury Branded Products. UTAR.

Makanyeza, C., \& Chikazhe, L. (2017). Mediators of the relationship between service quality and customer loyalty. International Journal of Bank Marketing.

Malhotra, N. K. (2018). Marketing Research: Current State and Next Steps. Brazilian Journal of Marketing-BJMkt Revista Brasileira de Marketing-ReMark Special Issue, 17, 18-41.

Mohd Suki, N. (2017). Green products usage: structural relationships on customer satisfaction and loyalty. International Journal of Sustainable Development \& World Ecology, 24(1), 88-95.

Mugenda, O. M., \& Mugenda, A. G. (2013). Research methods: Quantitative and qualitative approaches. Nairobi: Razoma.

Muturi, F. M., Omwenga, J., \& Owino, E. (2018). Determinants of brand loyalty in leading supermarket chains in Kenya. JKUAT-COHRED.

Ofori, K. S., Boakye, K., \& Narteh, B. (2018). Factors influencing consumer loyalty towards 3G mobile data service providers: evidence from Ghana. Total Quality Management \& Business Excellence, 29(5-6), 580598.

Owino, E.O., Kibera, F., Munyoki, J. \& Wainaina, G. (2014). Service Quality in Kenyan Universities: Dimensionality and Contextual Analysis, European Journal of Business and Management, 6(11) 180-193.

Razali, N. M., \& Wah, Y. B. (2011). Power comparisons of shapiro-wilk, kolmogorov-smirnov, lilliefors and anderson-darling tests. Journal of statistical modeling and analytics, 2(1), 21-33.

Saunders, M., Lewis, P., \& Thornhill, A. (2016). Research Methods for Business Students. 289-299. Harlow, England: Prentice Hall. Seidel, Saskia, Corinne Blanquart and Verena Ehrler.

Sehgal, M., \& Khanna, D. (2017). Factors Influencing Consumer Purchase Decisions at Organized Retail Stores in Ludhiana. International Journal of emerging research in management \& technology, 6(7), 56-64.

Vaccaro, V. L., Yucetepe, V., Cohn, D. Y., \& Dunne, J. H. (2017). Pleasant music's relationship to congruence, consumer behavioral intentions, unplanned purchase, and time spent in retail and service environments. Journal of International Management Studies, 17(2).

Wang, C.-Y. (2019). Cross-over effects of corporate reputation and store image: role of knowledge and involvement. Management Decision.

Grace Kiboro is currently a PhD Candidate in Business Adnimistration (Marketing Option) at Jomo Kenyatta University of Agriculture and Technology (JKUAT), Kenya. She holds an MBA specialising in Strategic Management and Leadership from the St. Paul's University Kenya; BSc in Chemistry from UON, Kenya and Diploma in Science Education from KSTC, Kenya. She is a senior marketing consultant in sales and marketing with ample experience in multinationals spanning for over two decades. She is a lecturer in business-marketing at St. Paul's University, Kenya. Her research interest is in Consumer Behaviour.

Prof. Mike Iravo is an Associate Professor and researcher at the school of business JKUAT, Kenya. He holds a Ph.D. in Business Administration from JKUAT, Kenya, a Master's in Administration and Planning from UON, Kenya; Masters of Arts from Sibiu University, Romania, Post Graduate Diploma in Education from Kenyatta University, Kenya; Diploma in Personnel Management \& Industrial Relations and Diploma of Principles Modern Management from College of Professional Management Jersey-London, United Kingdom.

Dr. Doris Mbugua is a Lecturer and Researcher at JKUAT Kenya, Department of Business Administration. She holds a PhD in Business Administration (Marketing), MBA (Marketing), International Diploma in Teaching and Training skills (City and Guilds), Diploma in Marketing and B.Sc. Biochemistry and Chemistry.

Dr. Edward Owino is a Senior Lecturer of Marketing Management at KCA University Kenya, Department of Business Administration. He holds a PhD Business Administration (Marketing), MBA (Marketing) and a Bachelor of Education Arts (Mathematics \& Economics). His research interest is in Service Marketing. 